Article

\title{
Impact of COVID-19 on Sustainable University Sports: Analysis of Physical Activity and Positive and Negative Affects in Athletes
}

\author{
Daniel Duclos-Bastías ${ }^{1}\left(\mathbb{D}\right.$, Felipe Vallejo-Reyes ${ }^{2}$, Frano Giakoni-Ramírez $^{3}\left(\mathbb{D}\right.$ and David Parra-Camacho ${ }^{4, *(1)}$ \\ 1 School of Physical Education, Pontificia Universidad Católica de Valparaíso, Valparaíso 2374631, Chile; \\ daniel.duclos@pucv.cl \\ 2 School of Psychology, Pontificia Universidad Católica de Valparaíso, Valparaíso 2374631, Chile; \\ felipe.vallejo@pucv.cl \\ 3 Faculty of Education, Universidad Autónoma de Chile, Temuco 4780000, Chile; frano.giakoni@uautonoma.cl \\ 4 Department of Physical Education and Sport, Universidad de Valencia, 46010 Valencia, Spain \\ * Correspondence: david.parra-camacho@uv.es
}

\section{check for}

updates

Citation: Duclos-Bastías, D.;

Vallejo-Reyes, F.; Giakoni-Ramírez, F.;

Parra-Camacho, D. Impact of

COVID-19 on Sustainable University

Sports: Analysis of Physical Activity

and Positive and Negative Affects in

Athletes. Sustainability 2021, 13, 6095.

https://doi.org/10.3390/su13116095

Academic Editors: Fernando

Lera-Lopez, Themistocles

Kokolakakis and Girish Ramchandani

Received: 30 April 2021

Accepted: 25 May 2021

Published: 28 May 2021

Publisher's Note: MDPI stays neutral with regard to jurisdictional claims in published maps and institutional affiliations.

Copyright: (c) 2021 by the authors. Licensee MDPI, Basel, Switzerland. This article is an open access article distributed under the terms and conditions of the Creative Commons Attribution (CC BY) license (https:// creativecommons.org/licenses/by/ $4.0 /)$.

\begin{abstract}
The suspension of university activities due to the pandemic affected training and sports competitions. However, some universities adapted online education, allowing students to carry out their activities without being infected by the virus. The aim of this study was to find out the impact of the pandemic on physical activity levels and the positive and negative effects on Chilean university athletes. The information was obtained by applying the PANAS scale and demographic and physical activity variables were also measured. The sample of Chilean university athletes $(n=254)$ were aged between 18 and 31 years $(M=22.17$; $S D=2.76)$. This study led to the conclusion that maintaining the frequency of physical training during the pandemic was associated with a preservation in the levels of Positive Affect and Negative Affect compared to the non-pandemic period. Thus, physical activity training was protective of emotional well-being and, therefore, of mental health.
\end{abstract}

Keywords: university athletes; COVID-19; physical activity; PANAS scale; positive and negative affects

\section{Introduction}

The social context created by the COVID-19 pandemic had a significant impact on different areas of human development over the last year. The outbreak of this type of virus, that was first identified in the Chinese city of Wuhan at the end of December 2019, and the rapid spread of its contagion [1,2] alerted health authorities at the international level. As a consequence, the World Health Organization (WHO) confirmed that the denomination of this new disease as COVID-19, whose origin is from a coronavirus, announced the pandemic status of this disease [3], which generated alarm around the world and concentrated a large part of government resources on mitigating its spread and effects.

One of the international public health strategies to contain the spread of COVID-19 has been confinement as an effective measure to reduce contagion [4]. In the case of Chile, this measure has been applied in several municipalities of the country, as instructed by the government [5]. According to the World Health Organization [6], this measure consists of social isolation and protection of people in their homes. In this regard, the Chilean health authority prepared an action plan for a gradual strategy. The same organization states that this strategy has undoubtedly implied a drastic change in the activities and behaviors of people in their daily lives, including work and online education, as well as restrictions in the practice of activities outside the home, forcing citizens to implement new ways of life inside their homes in the face of this contingency [6].

In addition, there is the restriction and prohibition of physical activity and sports as a result of the confinement measures and the limited progress made during the pandemic [5]. Sport, before the pandemic, was already attributed as an area that contributes to the 
development of society, due to its impact on human development, from a physical, social, inclusive, and economic dimension, becoming a relevant element in people's lives [7]. This has also been stated in the Sustainable Development Goals and their contribution, mainly in the goals: "Good health and well-being" and "Gender equality" [8]. Sustainability has therefore positioned itself as a feature increasingly present in sports organizations [9].

Consequently, the current emergency may have a great emotional impact [10,11], since confinement and situations of uncertainty are associated with increased affect and negative feelings [12]. In particular, in the case of universities, academic activities, and consequently university sports, have also been suspended on the recommendation of the health authority and in line with those indicated by the United Nations Educational, Scientific and Cultural Organization [13], which has forced the search for alternatives through virtual platforms to provide continuity to academic activities as well as physical and sporting activities of university students.

\subsection{Psychosocial Aspects in University Athletes}

In line with the above, and in relation to the university context and sustainability, it is important to note that the United Nations declared the period 2005-2014 as the "Decade of Education for Sustainable Development" [14]. In this period, the UN aimed to promote the integration of the principles and actions of sustainable development in all dimensions of education [15]. Successful experiences have been developed in the field of university sport, such as Seattle University's sustainable sport leadership certification program [16].

In the case of Chile, Article 1 of Law No 19.712 on Sport defines sport as a form of physical activity that uses human motor skills as a means of the integral development of people [17]. However, when we talk about university sport, it is more complex, mainly due to the difficulty of establishing its orientations. In this line, Martínez and García [18] present a classification of sport that allows us to identify among them the university sports whose purpose is to complement the training of higher education students. This distinction becomes necessary because its characteristics and beneficiaries will be quite specific. Almorza and Prada-Olivera [19] add that its objectives are framed in the improvement of health, physical condition, and quality of life, the development of physical qualities and motor skills, in addition to being an alternative for leisure time occupation, including a vehicle for establishing social relationships. That is in line with the Sustainable Development Goal "Good health and well-being" and in the sense of the United Nations' proposals for higher education institutions and their relation to sustainability. In this sense, sports performance is influenced by various factors, such as physiological, social, and psychological factors that impact on their results. In the case of university athletes, they are faced with various daily situations, such as intense training, lack of energy, economic difficulties, absences from university, competing, and other daily responsibilities [20]. This same author evidences in a study with athletes from the National Collegiate Athletic Association that athletes' negative relationships with family members predict higher levels of depression and mental health problems [20]. Whether biological or psychosocial factors, some of these variables, such as the athlete-coach relationship, can reduce burnout [21].

On the other hand, young people entering university perform insufficient physical activity, and this prevalence increases dramatically during the transition between adolescence and adulthood [22]. This implies a possible future risk associated with the well-being and health of this population, in addition to considerably modifying physical-sporting activity practices $[22,23]$. Along these lines, in the Chilean context, the work carried out prior to the COVID-19 pandemic [24,25], the lack of regular physical activity programs in Chilean universities, making this period a critical stage, which has an impact on students' health, was highlighted.

\subsection{Affections, Emotions, and Sustainability}

Understanding well-being as one of the fundamental objectives of sustainable development, and which has been defined as "a state of complete physical, mental, spiritual and 
social well-being and not merely the absence of disease or infirmity" [26,27]. Danner, Snowdon and Friesen [28] mention the need to include in particular the relationship between physical well-being and positive and negative emotions, since a person who feels good tends to have a more positive perception of reality and this has an effect both on themself and on others, and therefore on their own health. Therefore, positive perceptions of reality and adequate emotional management contribute to an integral development of the human being and their vital experience. Emotional perceptions of reality, according to Padrós, Soriano-Mas and Navarro [29], correspond to "dimensional constructs", which consider all affective states, both positive (joy, enthusiasm, falling in love, etc.) and negative (sadness, anger, fear and anxiety, etc.). Along these lines, authors such as Guillén, Bueno, Gutiérrez, and Guerra [30], define Positive Affect as that which comprises the terms opposed to vital dissatisfactions, while Negative Affect, on the other hand, warns about aspects related to loneliness, uselessness, and sadness, among others.

\subsection{Physical Activity and Affective Levels}

Some of the theories that attempt to explain from a psychological point of view the performance of physical activity, include the intention, the motivation to undertake the behavior, as well as the previous attitude of the subjects [31,32]. Moreover, the results found in studies that have related physical activity with other health behaviors, both with American and European samples, indicate that people who engage in some type of physical activity or sports practice, in addition to obtaining physical and psychological benefits, have healthier behaviors than physically inactive people $[33,34]$. These attitudes, motivations, and intentions are often subject to affective or emotional charges. In this same sense, it is possible to relate feelings or affects to affective states, affirming that feeling is the cognitive component of emotion. It is also defined as the evaluative dimension of reality that produces a Negative or Positive Affect. The feeling is more lasting and has less physiological affectation. Mood is a set of continuous feelings of the same emotional family (hopelessness, frustration, despair, discouragement, disappointment, nostalgia, etc.). All these terms are affective processes that we usually find in the generic denomination of "emotional" or "emotions". Reche-García et al. [35], who investigated physical exercise dependence and its moods, concluded that this dependence brings with it alterations in affective states. These generally have a directly proportional relationship.

\subsection{Affections and Confinement}

The situation presented by the pandemic caused by COVID-19 implied confinement measures and situations of uncertainty which led to increased affect and negative feelings [12]. In this line, a study was conducted by Ko, Yen, Yen and Yang [36] during the SARS outbreak in Taiwan where health authorities forced confinement. In the study, it was observed that the levels of depression during this quarantine period were the highest in that year (2003). While in another study conducted by Yoon, Kim, Ko and Lee [37] in the context of the Middle East Respiratory Syndrome (MERS) pandemic that affected South Korea, the confined participants in the sample showed a variation of negative affective states as the days of confinement increased, such as despair, anxiety, and anger.

The literature reviewed provides evidence that confinement situations affect people in a negative way. In particular, with regard to the population considered in the present study, a study conducted in Mexico during part of the confinement by COVID-19 in 2020, the students consulted presented stress (31.92\%), sleeping problems $(36.3 \%)$, and anxiety $(40.3 \%)$. They were followed by social dysfunction in daily activities $(9.5 \%)$, psychosomatic symptoms $(5.9 \%)$, and depression $(4.9 \%)$, especially in the female group and in younger students (18-25 years) [38]. In the same line, Lozano-Díaz, Fernández-Prados, Figueredo and Martínez [39] concluded in their study of the effects of COVID-19 confinement that the pandemic has not only strongly affected Spanish students, especially emotionally, but also academically, and the relationship that exists between all these aspects (dimensions) to achieve life satisfaction. Along the same lines, other studies have shown the effects of 
confinement on athletes, particularly due to exposure to high levels of stress, anxiety, and depressive symptoms as a result of the uncertainty generated by the health emergency, which have short- and long-term effects on physical condition, performance, and sleep quality $[40,41]$.

\subsection{Measurement of Affective States}

In the early 1980s, a certain theoretical interest was shown in the study of affective states, notably in the work of Watson and Tellegen [42], in which they carried out a reanalysis based on a large number of studies, suggesting conclusively that the two main factors are Positive Affect (PA) and Negative Affect (NA). These two dimensions are not correlatable, thus framing a first version of the Positive and Negative Affect Schedule (PANAS) instrument. Subsequently, Watson, Clark, and Tellegen [43] complemented the initial scale by separating the PA and NA into 10 items for each factor-the PA refers to how the person feels different emotions, such as enthusiasm, active, alert, energetic, and gratifying participation, while the NA refers to disgust, anger, guilt, fear, and nervousness [43]. This scale since its creation has great validity at an international level, being used as a measurement instrument in different psychobehavioral, socioemotional, and clinical studies. In the Chilean context, the work developed by the researchers Dufey and Fernández [44] made it possible to test its validity and effectiveness, particularly in a university population. The results showed that the psychometric properties of the PANAS scale are consistent with the literature, so the findings were consistent in terms of reliability and validity of the instrument with the original validation report [43]. In relation to the psychometric properties of the PANAS scale, these have been studied in relation to different instructions or temporal indications considered by time moments, namely: present, today, last days, last week, last weeks, last year, and in general. According to Dufey and Fernández [44], for all the periods evaluated, high estimates of internal consistency are observed, ranging from $\alpha=0.84$ to 0.90 , and the temporal stability for each time evaluated has been established for a period of eight weeks, with test-retest reliabilities ranging from moderate to high (between $r=0.39$ and $r=0.71$ ) [44]. According to the authors, regarding the validity of the scale, the correlation between the NA and PA subscales has been estimated at $r=-0.12$ to -0.23 , which is a good indicator of discriminant validity.

Therefore, the aim of this paper is to analyze the characteristics of physical activity and Positive and Negative Affect levels in athletes of university teams in the Valparaíso region and to contribute to the evidence and discussion of the effects of the pandemic on this population in order to improve decision making both for university sports departments and for coaches of the different teams.

\section{Materials and Methods}

\subsection{Participants}

The sample of the present study included 254 university students $(45.7 \%$ men and $54.3 \%$ women) who were members of the sports teams of six universities in the Valparaíso region: Pontificia Universidad Católica de Valparaíso (48\%), Universidad Andrés Bello (24.4\%), Universidad Técnica Federico Santa María (14.2\%), Universidad de Playa Ancha (10.2\%), Universidad de Valparaíso (1.6\%), and Universidad de Viña del Mar (1.6\%). The age range of the participants was 18 to 31 years $(\mathrm{M}=22.17$; $\mathrm{SD}=2.76)$, with an average age of 22 years $(S D=2.94)$ for men and $21(S D=2.52)$ for women. Inclusion criteria were that the participants had to be students enrolled in the year 2020 in one of the universities indicated, participate in a university sports team, and have agreed to participate in the study by signing the informed consent form.

\subsection{Instrument}

The instrument applied was structured in three sections (Table 1). The first requested type of information was sociodemographic variables, such as: sex, age, commune, university, sport, year of admission, and career. The second required types of information 
were on physical activity habits during the period comprising the pandemic, such as: days of weekly training, subjective assessment of the intensity of physical activity, and time spent on each training session. Finally, the third section presented the PANAS scale [43] validated for Chilean university students by Dufey and Fernández [44], which is divided into two subscales, one for Positive Affect (Enthusiastic, Interested, Determined, Excited, Inspired, Alert, Active, Strong, Proud and Attentive) and the other for Negative Affect (Scared, Afraid, Upset, Distressed, Jittery, Nervous, Ashamed, Guilty, Irritable and Hostile), and each of the items of the subscales are valued by means of a 5-level Likert scale being $1=$ very slightly or not at all; $2=$ a little; $3=$ moderately; $4=$ quite a bit; $5=$ extremely. The results of the validation of the scale for Chilean university students [44] concluded that the PANAS scales show psychometric properties consistent with previous literature and the results obtained were consistent in terms of reliability and validity of the original instrument. The reliability of the two dimensions of the scale presented an adequate value of Cronbach's alpha for the sample of this study $\alpha=0.86$.

Table 1. Instrument sections.

\begin{tabular}{cc}
\hline Section & Variables \\
\hline Sociodemographic Variables & $\begin{array}{c}\text { Sex, Age, Commune, University, Sport, Year of } \\
\text { admission, Career }\end{array}$ \\
\hline Physical Activity Habits & $\begin{array}{c}\text { Days of weekly training during the pandemic, } \\
\text { Subjective assessment of the intensity of physical } \\
\text { activity/exercise sessions (low, moderate, and vigorous), } \\
\text { Time spent on each training session }\end{array}$ \\
PANAS Scale & $\begin{array}{c}\text { PA: Enthusiastic, Interested, Determined, Excited, } \\
\text { Inspired, Alert, Active, Strong, Proud, Attentive } \\
\text { NA: Scared, Afraid, Upset, Distressed, Jittery, Nervous, } \\
\text { Ashamed, Guilty, Irritable, Hostile }\end{array}$ \\
\hline
\end{tabular}

\subsection{Procedure}

Firstly, a letter of invitation was sent to the sports departments of the universities to participate in the research, informing them of its objective and scope. Subsequently, once a favorable response was received, a list of student athletes from their institutions was requested, corresponding to the study population, with the following information: name and surname, team, and e-mail address. Once the information was received, a voluntary invitation e-mail was sent to the student athletes containing the link to the informed consent and the instrument containing the sociodemographic variables and physical activity habits during the pandemic together with the PANAS scale. In relation to the evaluation of the list of affects (positive and negative), the text "these moments" preceded it, i.e., the present time. A total of 254 responses were received with the signature of the informed consent and the instrument via the online form. Data were collected between September and October 2020 using non-probability convenience sampling. This sampling method was chosen because of the difficulty of conducting a probability sample as the research objectives did not aim for representativeness or generalizability of the results. Finally, we had access to a database of potential subjects who met the inclusion criteria, which also justified the use of this type of sampling.

\subsection{Statistical Analysis}

The results obtained were analyzed by means of descriptive and inferential statistics, using jamovi statistical software version 1.6.21. Descriptive statistics such as mean and standard deviation were extracted for the analysis of the variables. The absence of normal distribution of the data was checked using the Shapiro-Wilk and Kolmogorov-Smirnov test. For this reason, nonparametric mean comparison tests such as the Mann-Whitney $\mathrm{U}$ test and the chi-square test on categorical variables were used for the comparison of independent groups according to sex. 
Subsequently, a MANCOVA analysis was performed to determine the differential effect of the covariates sex, university, and the variables time, frequency, and intensity of training with respect to PA and NA. Finally, a Spearman correlation analysis was applied to test the relationship between the variables under study.

\section{Results}

\subsection{PANAS Variable Descriptives}

Table 2 shows the mean scores of the various indicators of the scale and the mean of the sum of the scores for each dimension: Positive Affect and Negative Affect. As can be seen, the mean score for Positive Affect is 31.20 (SD =6.75), while the mean score for Negative Affect is 20.95 (SD = 6.99). The indicators with the highest mean scores in the PA factor are Excited $(\mathrm{M}=3.44 ; \mathrm{SD}=0.96)$ and Active $(\mathrm{M}=3.34 ; \mathrm{SD}=1.04)$. In the case of NA, the indicators with a lower mean score are Hostile $(\mathrm{M}=1.84 ; \mathrm{SD}=0.95)$, Afraid $(\mathrm{M}=1.84$; $\mathrm{SD}=0.97)$, and Ashamed $(\mathrm{M}=1.54 ; \mathrm{SD}=0.88)$.

Table 2. Descriptive statistics of the PANAS scale.

\begin{tabular}{ccc}
\hline Affect & Mean & Standard Deviation \\
\hline Interested & 3.24 & 0.87 \\
Enthusiastic & 3.01 & 1.00 \\
Strong & 3.03 & 1.00 \\
Excited & 3.44 & 0.96 \\
Proud & 3.02 & 1.03 \\
Inspired & 2.83 & 1.11 \\
Determined & 3.15 & 1.02 \\
Attentive & 3.17 & 0.95 \\
Alert & 2.97 & 1.06 \\
Active & 3.34 & 1.04 \\
\hline Score Total Positive Affect (PA) & 31.20 & 6.99 \\
\hline Upset & 1.87 & 0.97 \\
Distressed & 2.17 & 1.08 \\
Guilty & 1.77 & 1.06 \\
Scared & 1.94 & 0.99 \\
Hostile & 1.84 & 0.95 \\
Afraid & 1.84 & 0.97 \\
Jittery & 2.74 & 1.20 \\
Irritable & 2.60 & 1.17 \\
Ashamed & 1.54 & 0.88 \\
Nervous & 2.64 & 1.20 \\
\hline Score Total Negative Affect (NA) & 20.95 & 6.75 \\
\hline
\end{tabular}

\subsection{Influence of Sex}

Table 3 presents the means and standard deviations corresponding to the volume of training days for the sample according to gender. Furthermore, it is evident that both distributions do not meet the assumption of normality. After testing for differences, it was observed that there were significant differences $(p<0.05)$ and that the average number of training days was higher in the group of men. 
Table 3. Volume of weekly training days according to the sex of the participants.

\begin{tabular}{ccc}
\hline Statistic & Group & $p$-Value \\
\hline \multirow{2}{*}{ M } & Men & 3.59 \\
& Women & 3.22 \\
& Total & 3.39 \\
\hline \multirow{2}{*}{ SD } & Men & 1.34 \\
& Women & 1.36 \\
& Total & 1.36 \\
\hline \multirow{2}{*}{ Shapiro-Wilk } & Men & $<0.001$ \\
& Women & $<0.001$ \\
\hline
\end{tabular}

Note. Non-parametric mean difference test, Mann-Whitney $\mathrm{U}, \chi^{2}=5.01, p=0.025$.

Table 4 presents the distribution of training intensity according to sex and complete sample. The chi-square test shows significant differences according to the sex of the athletes. According to the levels, it can be seen that the women's group has a higher proportion of moderate intensity than the men's. On the other hand, vigorous intensity is more frequent in men.

Table 4. Training intensity by sex of participants.

\begin{tabular}{ccccc}
\hline \multirow{2}{*}{ Group } & \multicolumn{3}{c}{ Intensity Level } & \multirow{2}{*}{ Total } \\
\cline { 2 - 4 } & Low & Moderate & Vigorous & \\
\hline Men & $9(\mathbf{\%})$ & $f(\mathbf{\%})$ & $f(\mathbf{\%})$ & $f(\mathbf{\%})$ \\
\hline Women & $21(8.57)$ & $65(26.53)$ & $42(17.14)$ & $116(47.34)$ \\
Total & $30(12.24)$ & $151(61.63)$ & $73(12.65)$ & $138(56.32)$ \\
\hline
\end{tabular}

Note. $\mathrm{Df}=$ degrees of freedom; $\mathrm{\chi}^{2}=7.53, \mathrm{df}=2, p=0.023$.

Table 5 shows significant differences between women and men with respect to the length of training sessions by time range. A greater concentration of women can be seen for shorter periods up to $75 \mathrm{~min}$, while men opt for longer workouts.

Table 5. Time spent on training according to sex and contrast of hypotheses.

\begin{tabular}{|c|c|c|c|}
\hline \multirow{2}{*}{ Range in Minutes } & \multicolumn{2}{|c|}{ Group } & \multirow{2}{*}{ Total } \\
\hline & Men & Women & \\
\hline & $f(\%)$ & $f(\%)$ & $f(\%)$ \\
\hline No time spent & $2(0.81)$ & $9(3.67)$ & $11(4.48)$ \\
\hline $30-45$ & $16(6.53)$ & $22(8.97)$ & $38(15.51)$ \\
\hline $46-60$ & $32(13.06)$ & $45(18.36)$ & $77(31.42)$ \\
\hline $61-75$ & $25(10.20)$ & $46(18.77)$ & $71(28.97)$ \\
\hline $76-90$ & $30(12.24)$ & $14(5.71)$ & 44 (17.95) \\
\hline$>90$ & $11(4.48)$ & $2(0.81)$ & $13(5.30)$ \\
\hline Total & $116(47.34)$ & $138(56.32)$ & $254(100)$ \\
\hline
\end{tabular}

Note. $\mathrm{df}=$ degrees of freedom; $\chi^{2}=24.1, \mathrm{df}=5, p \leq 0.001$.

Table 6 presents the results of the PANAS test factors for both test factors. Despite not respecting the assumption of normality, both kurtosis and skewness were less than 1.0, so it can be assumed that the distributions are close to normal. The mean comparison test confirmed the existence of statistically significant differences according to sex for the PA factor, although not for the NA factor. Males had a higher mean for the PA factor $(\mathrm{M}=32.5$; $\mathrm{SD}=6.71)$ and a lower mean for $\mathrm{NA}(\mathrm{M}=20.5$; $\mathrm{SD}=6.27)$. 
Table 6. PANAS scale factors by sex and total sample.

\begin{tabular}{cccc}
\hline \multirow{2}{*}{ Statistic } & Group & \multicolumn{2}{c}{ Factor PANAS } \\
\cline { 3 - 4 } & & PA & NA \\
\cline { 3 - 4 } M & Men & 32.5 & 20.5 \\
& Women & 30.1 & 21.3 \\
\hline \multirow{2}{*}{ SD } & Men & 6.71 & 6.27 \\
& Women & 6.60 & 7.54 \\
\hline Skewness & Total & -0.0466 & 0.716 \\
Kurtosis & Total & -0.416 & 0.123 \\
\hline Shapiro-Wilk p & Total & 0.151 & $<0.001$
\end{tabular}

Note. $\mathrm{M}=$ Mean; SD = Standard Deviation; $p=0.71$ for the Negative Affect (NA) factor and $p<0.001$ for the Positive Affect (PA) factor.

\subsection{Effects of Gender, University, Intensity, Minutes, and Days of Training}

Table 7 presents the results of a MANCOVA analysis that shows that the sex variable has a slight significance on the PA and NA factors, followed by the variable university and minutes of training. The most marked effect corresponds to intensity and days of training, while the smallest effect corresponds to the sex variable.

Table 7. MANCOVA analysis.

\begin{tabular}{ccccccc}
\hline Variable & Statistic & Valor & F & Df1 & Df2 & $p$-Value \\
\hline \multirow{2}{*}{ Sex } & Pillai's Trace & 0.0340 & 3.182 & 2 & 181 & 0.044 \\
& Wilks' Lambda & 0.966 & 3.182 & 2 & 181 & 0.044 \\
& Hotelling's Trace & 0.0352 & 3.182 & 2 & 181 & 0.044 \\
& Roy's Largest Root & 0.0352 & 3.182 & 2 & 181 & 0.044 \\
\hline \multirow{2}{*}{ University } & Pillai's Trace & 0.1011 & 2.193 & 10 & 412 & 0.017 \\
& Wilks' Lambda & 0.901 & 2.199 & 10 & 410 & 0.017 \\
& Hotelling's Trace & 0.1081 & 2.205 & 10 & 408 & 0.017 \\
& Roy's Largest Root & 0.0832 & 3.426 & 5 & 206 & 0.005 \\
\hline \multirow{2}{*}{ Intensity } & Pillai's Trace & 0.1585 & 8.864 & 4 & 412 & $<0.001$ \\
& Wilks' Lambda & 0.843 & 9.146 & 4 & 410 & $<0.001$ \\
& Hotelling's Trace & 0.1848 & 9.425 & 4 & 408 & $<0.001$ \\
& Roy's Largest Root & 0.1757 & 18.096 & 2 & 206 & $<0.001$ \\
\hline \multirow{2}{*}{ Minutes } & Pillai's Trace & 0.1230 & 2.699 & 10 & 412 & 0.003 \\
& Wilks' Lambda & 0.879 & 2.727 & 10 & 410 & 0.003 \\
& Hotelling's Trace & 0.1351 & 2.755 & 10 & 408 & 0.003 \\
& Roy's Largest Root & 0.1138 & 4.690 & 5 & 206 & $<0.001$ \\
\hline \multirow{2}{*}{ Days } & Pillai's Trace & 0.1479 & 15.708 & 2 & 181 & $<0.001$ \\
& Wilks' Lambda & 0.852 & 15.708 & 2 & 181 & $<0.001$ \\
& Hotelling's Trace & 0.1736 & 15.708 & 2 & 181 & $<0.001$ \\
& Roy's Largest Root & 0.1736 & 15.708 & 2 & 181 & $<0.001$ \\
\hline
\end{tabular}

Note. $\mathrm{Df}=$ degrees of freedom.

Table 8 disaggregates the effect observed on the dependent variables PA and NA. It can be seen that the sex variable only affects PA, but has no effect on NA. University affiliation has an effect on NA, but not on PA. The minutes of training proved to be significant on PA and even more so on NA. The number of days of training has a high significance on both PA and NA. 
Table 8. Univariate tests.

\begin{tabular}{ccccccc}
\hline & Factor & $\begin{array}{c}\text { Sum of } \\
\text { Squares }\end{array}$ & Df & $\begin{array}{c}\text { Mean } \\
\text { Squares }\end{array}$ & F & $p$-Value \\
\hline \multirow{2}{*}{ University } & PA & 282.55 & 5 & 56.51 & 1.5605 & 0.173 \\
& NA & 649.27 & 5 & 129.85 & 2.9861 & 0.013 \\
\hline \multirow{2}{*}{ Intensity } & PA & 1091.76 & 2 & 545.88 & 15.0746 & $<0.001$ \\
& NA & 428.99 & 2 & 214.49 & 4.9325 & 0.008 \\
\hline \multirow{2}{*}{ Minutes } & PA & 481.08 & 5 & 96.22 & 2.6570 & 0.024 \\
& NA & 681.64 & 5 & 136.33 & 3.1350 & 0.010 \\
\multirow{2}{*}{ Gender } & PA & 228.21 & 1 & 228.21 & 6.3020 & 0.013 \\
& NA & 1.19 & 1 & 1.19 & 0.0274 & 0.869 \\
\hline \multirow{2}{*}{ Days } & PA & 878.22 & 1 & 878.22 & 24.2523 & $<0.001$ \\
& NA & 388.53 & 1 & 388.53 & 8.9346 & 0.003 \\
\multirow{2}{*}{ Residues } & PA & 6590.58 & 182 & 36.21 & & \\
& NA & 7914.38 & 182 & 43.49 & & \\
\hline
\end{tabular}

Note. $\mathrm{Df}=$ degrees of freedom; $\mathrm{F}=$ test stadistic value.

\subsection{Relationship between Variables}

Table 9 shows the correlations between the study variables and their respective significance. A weak, although significant, negative correlation is observed between PA and NA. Days, intensity, and minutes of training correlate positively with PA in a decreasing manner. The correlation of days is moderate. For NA, the correlations of the training variables are all negative and significant, although the size of the coefficient is small. The correlations between all training variables are moderate and significant.

Table 9. PANAS correlation matrix and training variables.

\begin{tabular}{cccccc}
\hline & & PA & NA & Days & Intensity \\
\hline \multirow{2}{*}{ NA } & $r$ & -0.196 & & & \\
& $p$ & 0.002 & & & \\
Days & $r$ & 0.412 & -0.250 & & \\
& $p$ & $<0.001$ & $<0.001$ & & \\
Intensity & $r$ & 0.334 & -0.199 & 0.511 & \\
& $p$ & $<0.001$ & 0.001 & $<0.001$ & \\
Minutes & $r$ & 0.237 & -0.160 & 0.492 & 0.587 \\
& $p$ & $<0.001$ & 0.011 & $<0.001$ & $<0.001$ \\
\hline
\end{tabular}

Note. $r$ = correlation coefficient.

\section{Discussion}

As a result of the advent of COVID-19, home confinement has been adopted as a mandatory measure in many parts of the world, and although its main objective is to reduce contagion, it involves other health risks, such as stress, anxiety, sleep disturbances, and mood disorders [45]. Confinement as a preventive measure has benefits, but also adverse or undesirable effects in the general population, so urgent measures are suggested to mitigate the negative effects on people's mental health [21], also considering the benefits of physical activity and increased well-being and resilience [46]. In relation to university athletes, the measures have also had adverse effects, as they have limited the possibility of athletes to continue at a competitive level and to participate in tournaments, affecting the levels of physical activity, anxiety, demotivation, and in some cases burnout syndrome [21].

In relation to the above, it is highlighted that, during confinement, male university athletes who participated in this study obtained a higher average number of days $(\mathrm{M}=3.59)$ and training time compared to women $(\mathrm{M}=3.22)$, although the difference does not reach one day; in the same line of the results obtained in the study of Şenışık et al. [47], who inquired about mental health in athletes in the COVID-19 pandemic period. In addition, 
the intensity of exercise in female athletes was mostly of low and moderate intensity, while for the male sample it was of a more frequent vigorous intensity. However, in relation to the measurement of physical activity levels (frequency and intensity), the present study had limitations, as the measurement was subjective and self-administered, which has a correlation of no more than $50 \%$ with objective measures such as accelerometers by the athletes [48]. These results coincide with those obtained by Rico-Gallegos et al. [49], who analyzed physical activity habits and health status during the pandemic; $46.35 \%$ of the sample performed low physical activity, especially women with $49.39 \%$, compared with $39.13 \%$ of men. This is contrary to what was evidenced in the work of Villaseca-Vicuña et al. [50], who concluded that the training load in Chilean female soccer players was maintained at the same levels as before the beginning of the pandemic, which could be explained by their condition as professional athletes.

In the same line and ratifying the results obtained, Castillo et al. [34] affirm that in general, people who engage in some type of sports practice, in addition to obtaining physical and psychological benefits, have healthier behaviors than physically inactive people. These attitudes, motivations, and intentions are often subject to affective changes, which is closely related to moods [30].

As a result of the above, another objective of the present study was to assess PA and NA in university athletes during the pandemic period due to the COVID-19 virus, where it was found that PA was superior to NA, being similar and descriptively superior to the results obtained by Dufey and Fernández for PA and NA in the present tense ("at this moment") [44]. This may be explained by the fact that although the study was conducted during a non-pandemic period, it looked at ordinary university students, that is a nonsporting population, whose PA values tend to be lower than the sporting population [34]. Within the NA, the Hostile and Afraid states were highlighted, and in the PA, the Excited and Active states were highlighted. The results obtained corroborate what was stated by Reche-García et al. [35], who affirm that physical exercise and mood states have a directly proportional relationship, which was demonstrated by the maintenance of the non-presence training of the studied sample during the confinement period. Furthermore, a descriptively similar ratio between PA and NA scores was observed to those reviewed in the literature.

In relation to this, and taking into consideration what was evidenced by Reche-García et al. [35], the results obtained are corroborated on the basis that the male and female university athletes who participated in this study presented a significant difference of greater PA with respect to NA. The latter could be associated with the higher training volume of the male sample and the positive correlation between training volume and PA observed in the present study.

Finally, it is important to consider that the results obtained are only representative for the purposes of the sample analyzed, considering as a limitation the lack of knowledge of the levels of physical activity and NA and PA pre-pandemic, which could be addressed in the future by considering a control group of non-sporting university students or by conducting field experiments, such as the one carried out by Bühren and Steinberg [51].

\section{Conclusions}

The global impact of the pandemic due to the outbreak of COVID-19 affected higher education institutions, causing the suspension of their activities, and consequently, affecting university athletes in their on-site training processes and the suspension of national and international competitions. In order to know the effects on physical activity and the positive and negative effects of pandemic control measures, such as confinement and physical distancing in university athletes, the present study investigated the levels of physical activity and the positive and negative effects of a sample of Chilean university athletes. Based on the above, it can be concluded that, in the case of the sample analyzed, maintaining a frequency, intensity, and duration of training-type physical activity during the pandemic was associated with a preservation of Positive Affect and a level of Negative 
Affect similar to non-pandemic periods in non-sporting samples. Thus, having performed such training in both the female and male samples acted as an effective agent to enhance the affective states, and therefore the mental health, of the athletes.

Author Contributions: Conceptualization: D.D.-B., F.V.-R.; methodology: D.P.-C. and F.V.-R.; software: D.P.-C. and F.V.-R.; formal analysis: D.P.-C. and F.V.-R.; investigation: D.P.-C., F.G.-R. and D.D.-B.; data curation: D.D.-B. and D.P.-C.; writing-original draft preparation: D.D.-B., D.P.-C., F.G.-R. and D.D.-B.; writing-review and editing: D.D.-B., D.P.-C., F.G.-R. and F.V.-R.; visualization: D.P.-C., F.G.-R. and D.D.-B.; supervision: D.P.-C., F.G.-R. and D.D.-B. All authors have read and agreed to the published version of the manuscript.

Funding: This research received no external funding.

Institutional Review Board Statement: Not applicable.

Informed Consent Statement: The research has adhered to ethical practices that include, fundamentally, the informed consent of the participants and adherence to the guidelines for the practice of good publications, developed by the Publications Ethics Committee (COPE, 1997).

Data Availability Statement: Not applicable.

Conflicts of Interest: The authors declare no conflict of interest.

\section{References}

1. Giovanetti, M.; Benvenuto, D.; Angeletti, S.; Ciccozzi, M. The First Two Cases of 2019-NCoV in Italy: Where They Come From? J. Med. Virol. 2020, 92, 518-521. [CrossRef]

2. Watkins, J. Preventing a Covid-19 Pandemic. BMJ 2020, 368, m810. [CrossRef]

3. Intervención del Director General de la OMS en la Conferencia de Prensa Sobre el 2019-nCoV del 11 de Febrero de 2020. Available online: https:/ / www.who.int/es/director-general/speeches/detail/who-director-general-s-remarks-at-the-media-briefingon-2019-ncov-on-11-february-2020 (accessed on 11 April 2021).

4. Kucharski, A.J.; Russell, T.W.; Diamond, C.; Liu, Y.; Edmunds, J.; Funk, S.; Eggo, R.M.; Sun, F.; Jit, M.; Munday, J.D.; et al. Early Dynamics of Transmission and Control of COVID-19: A Mathematical Modelling Study. Lancet Infect. Dis. 2020, 20, 553-558. [CrossRef]

5. Gobierno Anunció Cierre de Cines, Restaurantes y Actividades Deportivas. Available online: https://www.minsal.cl/gobiernoanuncio-cierre-de-cines-restaurantes-y-actividades-deportivas/ (accessed on 11 April 2021).

6. Updated WHO Recommendations for International Traffic in Relation to COVID-19 Outbreak. Available online: https: / / www.who.int/news-room/articles-detail/updated-who-recommendations-for-international-traffic-in-relation-to-covid-19 -outbreak (accessed on 5 April 2021).

7. Pfahl, M. The Environmental Awakening in Sport. Solut. J. 2016, 4, 67-76.

8. Take Action for the Sustainable Development Goals-United Nations Sustainable Development. Available online: https: //www.un.org/sustainabledevelopment/sustainable-development-goals/ (accessed on 30 April 2021).

9. McCullough, B.P.; Orr, M.; Watanabe, N.M. Measuring Externalities: The Imperative Next Step to Sustainability Assessment in Sport. J. Sport Manag. 2019, 34, 393-402. [CrossRef]

10. Lima, C.K.T.; de Medeiros Carvalho, P.M.; Lima, I.D.A.A.S.; de Oliveira Nunes, J.V.A.; Saraiva, J.S.; de Souza, R.I.; da Silva, C.G.L.; Neto, M.L.R. The Emotional Impact of Coronavirus 2019-NCoV (New Coronavirus Disease). Psychiatry Res. 2020, $287,112915$. [CrossRef]

11. Xiang, Y.-T.; Yang, Y.; Li, W.; Zhang, L.; Zhang, Q.; Cheung, T.; Ng, C.H. Timely Mental Health Care for the 2019 Novel Coronavirus Outbreak Is Urgently Needed. Lancet Psychiatry 2020, 7, 228-229. [CrossRef]

12. Lades, L.K.; Laffan, K.; Daly, M.; Delaney, L. Daily Emotional Well-Being during the COVID-19 Pandemic. Br. J. Health Psychol. 2020, 25, 902-911. [CrossRef] [PubMed]

13. El Coronavirus COVID-19 y la Educación Superior: Impacto y Recomendaciones; UNESCO-IESALC: Caracas, Miranda, Venezuela, 2020.

14. The UN Decade of Education for Sustainable Development (DESD 2005-2014): The First Two Years; UNESCO: Paris, France, 2008; 64p.

15. Carolee, B.; Heather, C. Shaping the Future We Want: UN Decade of Education for Sustainable Development; Final Report; UNESCO: Paris, France, 2014; ISBN 978-92-3-100053-9.

16. Program: Certificate in Sport Sustainability Leadership—Seattle University—Acalog ACMSTM. Available online: https://catalog. seattleu.edu/preview_program.php?catoid=28\&poid=6539 (accessed on 29 April 2021).

17. Biblioteca Del Congreso Nacional. Ley Chile. Available online: https://www.bcn.cl/leychile (accessed on 5 April 2021).

18. Yepes, J.G.M.; Díaz, Á.J.G. El deporte, otras vertientes y la diversidad de sus clasificaciones. Lúdica Pedagóg. 2000, 4. [CrossRef]

19. Almorza, D.; Prada, A. Estudio diagnóstico del deporte universitario español. Ibero-Am. J. Exerc. Sports Psychol. 2019, 14, 89-90.

20. Hussey, J. Examination of Mental Health and Family Relationship in Collegiate Athletes. UNLV Theses Diss. Prof. Pap. Capstones 2018, 1, 1-74. [CrossRef] 
21. Davis, L.; Stenling, A.; Gustafsson, H.; Appleby, R.; Davis, P. Reducing the Risk of Athlete Burnout: Psychosocial, Sociocultural, and Individual Considerations for Coaches. Int. J. Sports Sci. Coach. 2019, 14, 444-452. [CrossRef]

22. Van Mechelen, W.; Twisk, J.W.R.; Post, G.B.; Snel, J.; Kemper, H.C.G. Physical Activity of Young People: The Amsterdam Longitudinal Growth and Health Study. Med. Sci. Sports Exerc. 2000, 32, 1610-1616. [CrossRef] [PubMed]

23. Wengreen, H.J.; Moncur, C. Change in Diet, Physical Activity, and Body Weight among Young-Adults during the Transition from High School to College. Nutr. J. 2009, 8, 32. [CrossRef] [PubMed]

24. Rodríguez-Rodríguez, F.; Cristi-Montero, C.; Villa-González, E.; Solís-Urra, P.; Chillón, P.; Rodríguez-Rodríguez, F.; CristiMontero, C.; Villa-González, E.; Solís-Urra, P.; Chillón, P. Comparación de Los Niveles de Actividad Física Durante La Vida Universitaria. Rev. Méd. Chile 2018, 146, 442-450. [CrossRef]

25. Durán, S.; Castillo, M.; Vio del, F. Diferencias En La Calidad de Vida de Estudiantes Universitarios de Diferente Año de Ingreso Del Campus Antumapu. Rev. Chil. Nutr. 2009, 36, 200-209. [CrossRef]

26. WHO. Workers' Health: Global Plan of Action. Available online: https://www.who.int/occupational_health/publications/ global_plan/en/ (accessed on 29 April 2021).

27. Macik-Frey, M.; Quick, J.C.; Nelson, D.L. Advances in Occupational Health: From a Stressful Beginning to a Positive Future. J. Manag. 2007, 33, 809-840. [CrossRef]

28. Danner, D.D.; Snowdon, D.A.; Friesen, W.V. Positive Emotions in Early Life and Longevity: Findings from the Nun Study. J. Personal. Soc. Psychol. 2001, 80, 804-813. [CrossRef]

29. Padrós Blázquez, F.; Soriano-Mas, C.; Navarro Contreras, G. Afecto Positivo y Negativo: ¿Una Dimensión Bipolar o Dos Dimensiones Unipolares Independientes? [Positive and Negative Affect: One Bipolar Dimension or Two Independent Unipolar Dimensions]. Interdiscip. Rev. Psicol. Cienc. Afines 2012, 29, 151-164. [CrossRef]

30. Pereira, L.G.; Fernandez, E.B.; Cruz, M.G.; Santiesteban, J.R. Programa de actividad física y su incidencia en la depresión y bienestar subjetivo de adultos mayores (Impact of a physical activity program on older adults' depression and subjective well-being). Retos 2018, 33, 14-19. [CrossRef]

31. Bandura, A. Social Cognitive Theory for Personal and Social Change by Enabling Media. In Entertainment-Education and Social Change: History, Research, and Practice; LEA's Communication Series; Lawrence Erlbaum Associates Publishers: Mahwah, NJ, USA, 2004; pp. 75-96. ISBN 978-0-8058-4552-5.

32. Noar, S.M.; Zimmerman, R.S. Health Behavior Theory and Cumulative Knowledge Regarding Health Behaviors: Are We Moving in the Right Direction? Health Educ. Res. 2005, 20, 275-290. [CrossRef]

33. Chatzisarantis, N.L.D.; Kee, Y.H.; Thaung, H.K.; Hagger, M.S. When Small Losses Do Not Loom Larger than Small Gains: Effects of Contextual Autonomy Support and Goal Contents on Behavioural Responses to Small Losses and Small Gains. Br. J. Soc. Psychol. 2012, 51, 690-708. [CrossRef] [PubMed]

34. Castillo, I.; Balaguer Solá, I.; García-Merita, M. Efecto de la práctica de actividad física y de la participación deportiva sobre el estilo de vida saludable en la adolescencia en función del género. Rev. Psicol. Deporte 2007, 16, 0201-0210.

35. Reche-García, C.; Martínez-Rodríguez, A.; Ortín-Montero, F.J. Dependencia al ejercicio físico e indicadores del estado de ánimo en deportistas universitarios. Cuad. Psicol. Deporte 2015, 15, 21-26. [CrossRef]

36. Ko, C.-H.; Yen, C.-F.; Yen, J.-Y.; Yang, M.-J. Psychosocial Impact among the Public of the Severe Acute Respiratory Syndrome Epidemic in Taiwan. Psychiatry Clin. Neurosci. 2006, 60, 397-403. Available online: https://onlinelibrary.wiley.com/doi/full/10.1 111/j.1440-1819.2006.01522.x (accessed on 11 April 2021). [CrossRef] [PubMed]

37. Yoon, M.-K.; Kim, S.-Y.; Ko, H.-S.; Lee, M.-S. System Effectiveness of Detection, Brief Intervention and Refer to Treatment for the People with Post-Traumatic Emotional Distress by MERS: A Case Report of Community-Based Proactive Intervention in South Korea. Int. J. Ment. Health Syst. 2016, 10, 51. [CrossRef]

38. Jaimes, N.L.G.; Alcántara, A.A.T.; Méndez, C.M.; Hernández, Z.O.O. Impacto Psicológico En Estudiantes Universitarios Mexicanos Por Confinamiento Durante La Pandemia Por COVID-19: Psychological Impact on Mexican University Students Due to Confinement during the Covid-19 Pandemic; Scielo Preprints: Sao Paulo, Brasil, 2020. [CrossRef]

39. Lozano-Díaz, A.; Fernández-Prados, J.S.; Canosa, V.F.; Martínez, A.M.M. Impactos del confinamiento por el COVID-19 entre universitarios: Satisfacción Vital, Resiliencia y Capital Social Online. Int. J. Sociol. Educ. 2020, 79-104. [CrossRef]

40. Jukic, I.; Calleja-González, J.; Cos, F.; Cuzzolin, F.; Olmo, J.; Terrados, N.; Njaradi, N.; Sassi, R.; Requena, B.; Milanovic, L.; et al. Strategies and Solutions for Team Sports Athletes in Isolation Due to COVID-19. Sports 2020, 8, 56. [CrossRef]

41. Altena, E.; Baglioni, C.; Espie, C.A.; Ellis, J.; Gavriloff, D.; Holzinger, B.; Schlarb, A.; Frase, L.; Jernelöv, S.; Riemann, D. Dealing with Sleep Problems during Home Confinement Due to the COVID-19 Outbreak: Practical Recommendations from a Task Force of the European CBT-I Academy. J. Sleep Res. 2020, 29, e13052. [CrossRef]

42. Watson, D.; Tellegen, A. Toward a Consensual Structure of Mood. Psychol. Bull. 1985, 98, 219-235. [CrossRef]

43. Watson, D.; Clark, L.A.; Tellegen, A. Development and Validation of Brief Measures of Positive and Negative Affect: The PANAS Scales. J. Personal. Soc. Psychol. 1988, 54, 1063-1070. [CrossRef]

44. Dufey, M.; Fernández, A.M. Validez y confiabilidad del Positive Affect and Negative Affect Schedule (PANAS) en estudiantes universitarios chilenos. Rev. Iberoam. Diagn. Eval. Psicol. 2012, 2, 157-173.

45. Roy, D.; Tripathy, S.; Kar, S.K.; Sharma, N.; Verma, S.K.; Kaushal, V. Study of Knowledge, Attitude, Anxiety \& Perceived Mental Healthcare Need in Indian Population during COVID-19 Pandemic. Asian J. Psychiatry 2020, 51, 102083. [CrossRef] 
46. Yoshikawa, E.; Nishi, D.; Matsuoka, Y.J. Association between Regular Physical Exercise and Depressive Symptoms Mediated through Social Support and Resilience in Japanese Company Workers: A Cross-Sectional Study. BMC Public Health 2016, 16, 553. [CrossRef]

47. Şenışık, S.; Denerel, N.; Köyağasığlu, O.; Tunç, S. The Effect of Isolation on Athletes' Mental Health during the COVID-19 Pandemic. Physician Sportsmed. 2020, 49, 187-193. [CrossRef]

48. Medina, C.; Barquera, S.; Janssen, I. Validity and Reliability of the International Physical Activity Questionnaire among Adults in Mexico. Rev. Panam Salud Publica 2013, 34, 21-28.

49. Rico-Gallegos, C.; Vargas Esparza, G.; Poblete-Valderrama, F.A.; Carrillo-Sanchez, J.L.; Rico-Gallegos, J.; Mena-Quintana, B.; Chaparro-Baeza, D.K.; Resendiz-Hernandez, J.M. Hábitos de Actividad Física y Estado de Salud Durante La Pandemia Por COVID-19. Rev. ESPACIOS 2020, 41, 1-10. [CrossRef]

50. Villaseca-Vicuña, R.; Pérez-Contreras, J.; Merino-Muñoz, P.; González-Jurado, J.; Aedo-Muñoz, E. Efectos de las medidas de confinamiento por COVID-19 en el grado de bienestar y la carga de entrenamiento de las jugadoras de la selección nacional de fútbol de Chile. Rev. Fac. Med. 2021, 69, 1-7. [CrossRef]

51. Bühren, C.; Steinberg, P.J. The Impact of Psychological Traits on Performance in Sequential Tournaments: Evidence from a Tennis Field Experiment. J. Econ. Psychol. 2019, 72, 12-29. [CrossRef] 